\title{
ŻEGLUGA BENIOWSKIEGO \\ WZDŁUŻ WYBRZEŻY AZJI WSCHODNIEJ \\ W ŚWIETLE NAJNOWSZYCH ODKRYĆ (WYSPY BONIN, JAPONIA, WYSPY LIUQIU, CHINY, MAKAU)
}

Od sensacyjnego dla biografów Maurycego Beniowskiego i historyków żeglugi odkrycia w Warszawie jego uznawanej za zaginioną mapy żeglugi przez Morze Beringa i południowy Pacyfik w listopadzie 2011 r. minęło już wprawdzie niemal 7 lat, lecz nie udało mi się dotychczas spowodować zainteresowania tym wydarzeniem polskich wydawnictw i instytucji naukowych. Odbiło się ono jednak w ostatnim czasie głośnym echem nie tylko w Europie, ale również w Azji.

Odnaleziona po upływie 240 lat od czasu jej wykreślenia mapa Beniowskiego, ukazująca trasę jego żeglugi po wodach północnego Pacyfiku, stanowi niewątpliwie bardzo cenne, a dotąd brakujące ogniwo w poszukiwaniu prawdy o jego dokonaniach jako żeglarza i odkrywcy. Najpierw kilka słów o samym jej odnalezieniu w zbiorach Centralnej Biblioteki Instytutu Geografii i Przestrzennego Zagospodarowania Państwowej Akademii Nauk w Warszawie, której kierownikiem jest Dorota Gazicka-Wojtowicz. Odkrycia dokonała w końcu 2011 r. Małgorzata Bandzo-Antkowiak, kierownik Gabinetu Zbiorów Kartograficznych Biblioteki Uniwersyteckiej w Warszawie. Na zaproszenie obu pań w listopadzie $2011 \mathrm{r}$. mogłem obejrzeć tę mapę i podzielić się moimi uwagami dotyczacymi jej autentyczności i ważności dla badaczy biografii Beniowskiego oraz historii odkryć geograficznych na Pacyfiku.

Najwcześniejszy komunikat o tym odkryciu został opublikowany w Gdańsku już w 2012 r. ${ }^{1}$, przy moim artykule o żegludze Beniowskiego u wybrzeży Japonii ${ }^{2}$. Nie powoływałem się w nim jeszcze na informacje z mapy, nie mając do tego upoważnienia. Krótki anglojęzyczny tekst na temat odnalezionej mapy ukazał się dopiero we wrześniu 2013 r. w kwartalniku „Geographia Polonica”3 z załączoną w całości mapa, bez próby odpowiedzi na postawione pytania. Od tego czasu zaczęła ona

1 M. Bandzo-Antkowiak, Odnaleziona mapa Maurycego Augusta Beniowskiego. Komunikat, „Gdańskie Studia Azji Wschodniej” 2012, z. 2, s. 111-113.

2 E. Kajdański, Beniowski u mybrzę̇y Japonii, „Gdańskie Studia Azji Wschodniej” 2012, z. 2, s. $99-110$.

3 M. Bandzo-Antkowiak, Maurice August Beniowski - Confabulator or Discoverer? Map of his Journey found, „Geographia Polonica” 2013, vol. 86, issue 2, s. 171-173. 
już pojawiać się wraz z interpretacjami w licznych publikacjach zagranicznych. Moje własne wnioski i wstępne interpretacje przedstawiłem po raz pierwszy w książce wydanej w 2015 r. przez Narodowe Muzeum Morskie w Gdańsku .

Sporządzony w języku francuskim tytuł mapy: Carte de la Mer Oriental du Nord entre les Costes de l'amerique Occidentale et celles de la Tartarie Orientale, avec les Isles Nouvelle decouvert dedié a Monseigneur le Duc d'aiguillon Paire de France Ministre et Secretaire d'Etatpar M. Maurice Auguste de Benyows zky 1772 wskazuje, że miała ona stać się nieodłączną częścią Džiennika żeglugi morskiej zpótwyspu Kamczatka do Kantonu w Chinach, stanowiącego drugi tom Pamiętników Beniowskiego. O dzienniku tym wiemy, że po przybyciu do Port Louis we Francji Beniowski przekazał go ministrowi spraw zagranicznych Francji, księciu d'Aiguillon, przebywającemu wówczas w Compiegne ${ }^{5}$.

Zanim przystąpię do omówienia poszczególnych etapów żeglugi, kilka słów o samej mapie i o występujących na niej błędach. Została ona opisana po francusku. Jej autentyczność oraz fakt przekazania (jako przynależnej do Driennika żeglugi) władzom francuskim zostały potwierdzone pieczęcią Ministerstwa Spraw Zagranicznych Republiki Francuskiej. Pytanie, z jakiego okresu pochodzi ta pieczęć, pozostaje na razie moim zdaniem otwarte, podobnie jak czas i okoliczności, w jakich trafiła do Polski. U dołu mapy widzimy napis informujący, że południkiem zerowym jest na niej południk paryski, a nie południk de Ferro, jak to zostało stwierdzone w „Geographia Polonica" (Longitude orientale du Meridien de Paris) ${ }^{6}$. Powinno to raczej wykluczyć domniemanie, że odnaleziony egzemplarz mapy mógł być sporządzony jeszcze w trakcie żeglugi przez Pacyfik. Stan zachowania także wykluczał używanie jej na pokładzie statku, a poza tym na pierwotnej wersji powinien był figurować południk bolszeriecki jako zerowy (i być może de Ferro, gdyż w połowie trasy Beniowski zaczął korzystać z hiszpańskiej mapy z Podróży lorda Ansona) ${ }^{7}$. Jestem zwolennikiem tezy, że mapa powstała już po jego przybyciu do Francji, być może na żądanie Ministerstwa Marynarki i Kolonii, do którego powinien był trafić Driennik żeglugi.

Na taką ewentualność wskazuje kilka okoliczności. Na mapie mamy zaznaczona trasę żeglugi przez Pacyfik z adnotacjami autora: Route suivre par le Galeotte Saint Pier en 1771 Commandante par Maurice Auguste de Benyowszky oraz w dolnej części mapy: Suite de la même Route (tj. ciąg dalszy wymienionej trasy). Bardzo ważnym szczegółem odnalezionej mapy jest to, że przedstawia ona - wytyczoną linia przerywaną - pełną 134-dniową trasę żeglugi „Św. Piotra i Pawła” z Kamczatki do Makau. Ponadto na całej długości ukazanej trasy żeglugi większymi punkcikami zaznaczone zostały miejsca, w których dokonywane były codzienne pomiary długości i szerokości geo-

4 E. Kajdański, Odkrywca cåy blagier? Maurycy Beniowski na Pacyfiku, Gdańsk 2015.

5 Beniowski podjął decyzję oddania się pod protektorat Francji dopiero w końcu 1771 r., gdy przebywał w Makau.

6 Zob. M. Bandzo-Antkowiak, Maurice August Beniowski..., tu: mapa i s. 173.

7 Francuskie ich wydanie było w posiadaniu jednego z zesłańców, Piotra Chruszczowa vel Chrustowskiego. 
graficznych, sondowań, czyli pomiarów głębokości, pobierania gruntu etc. Wszystkie te miejsca są mniej lub bardziej dokładnie skorelowane z zapisami w Drienniku żeglugi, co oznacza, że jesteśmy w stanie prześledzić ruchy statku i jego położenia w czasie każdego ze 134 dni przebywania na morzu lub kotwiczenia u różnych wybrzeży. Mapa Beniowskiego nie grzeszy dokładnościa, szczególnie jeżeli sprawdzimy jego długości geograficzne, lecz biorąc pod uwagę sprzęt pomiarowy, jakim dysponował, jego błędy nie odbiegają od ówczesnych map rosyjskich czy też wcześniejszych hiszpańskich, z których korzystał ${ }^{8}$. Były to wymienione w Pamietnikach mapy Beringa, Spanberga, Sindta z lat 1741-1765 oraz hiszpańska mapa sprzed roku 1744 z francuskiego egzemplarza Podróśy lorda Ansona.

W swej ksiażce Wyspy Komandorskie Benedykt Dybowski cytuje wypowiedź uczestnika drugiej ekspedycji Beringa, G.W. Stellera o wyrzuceniu w 1742 r. statku Beringa „Św. Piotr” na nieznaną wówczas Wyspę Beringa. Wszyscy oficerowie statku byli przekonani, że znajdowali się już na wschodnim wybrzeżu Kamczatki, w Zatoce Awaczyńskiej:

Z jakąż radością ujrzeliśmy na koniec ziemię w dniu 5 listopada - cytuje Dybowski słowa uczestnika tej podróży Stellera. - Z początku zdawało się nam, że widzimy Kamczatkę w rzeczywistości była to wyspa bezludna. Nawet na wpół żywi wywlekli się na pokład, aby zobaczyć ziemię, a każdy z głębi serca dziękował Bogu za jego miłosierdzie. Nie wiedząc, gdzie się naprawdę znajdują, przechwalali się głośno oficerowie, że choćby tysiąc wybrać najlepszych żeglarzy, żaden z nich nie potrafiłby lepiej dotrzeć do celu: „Nie chybiliśmy ani pół mili" - twierdzili oni. Powszechne było mniemanie, że stanęliśmy u wejścia do Zatoki Awaczyńskiej, a nawet zdawało się niektórym, że poznają już oddzielne góry. Dopiero wtedy wyszła na jaw omyłka, gdy okrążywszy niewielki przylądek, nie znaleziono dobrze im znanych wysepek; pomimo to nie zwatpili jeszcze, jakoby ziemia ta nie była Kamczatką?.

Błędy w obliczeniach czy raczej w szacunkach oficerów Beringa wyniosły w tym przypadku 8 stopni długości i 2 stopnie szerokości. Podobne błędy długości geograficznych popełniał niekiedy także Beniowski, głównie w trakcie żeglugi ze wschodu na zachód. Zauważmy przy tym, że odległości na mapie Beniowskiego wyrażone w stopniach długości sa przeważnie wyższe niż w rzeczywistości, przez co jest ona jak gdyby „rozciagnięta”, co szczególnie jest widoczne przy odcinkach tras biegnących poziomo - ze wschodu na zachód. Jedna z przyczyn tych błędów, poza nieuwzględnianiem dewiacji, jest niewątpliwie połączenie w jedną całość niezbyt dokładnych map rosyjskich i hiszpańskich oraz nałożenie na nie

8 Podkreślałem już we wcześniejszych moich pracach, że korzystał on z niedokładnego kwadrantu Daviesa (back-staff), laski Jakuba (cross-staff) i logu ręcznego, płynąc zupełnie nieznanymi trasami, z nieznanymi prądami i na znacznej przestrzeni przez obszary pokryte lodem, śniegiem i mgłami. Zob. E. Kajdański, Odkerywca csy blagier?..., s. 31 i nn.

9 B. Dybowski, Wyspy Komandorskie, Lwów 1885, s. 2-3. 
wspólnej siatki geograficznej. Poza tym widoczny jest tu także celowy moim zdaniem brak dokładności przy zaznaczaniu miejsc kotwiczeń statku, wynikający być może z upływu czasu lub z niechęci do przedwczesnego ujawnienia we Francji szczegółów żeglugi. Można te niedokładności traktować jako potwierdzenie, że Beniowski nie wykreślił swojej mapy w $1771 \mathrm{r}$. w Makau, gdy miał jeszcze świeżo w pamięci wszystkie wydarzenia z podróży, tylko już po przybyciu w lipcu $1772 \mathrm{r}$. do Francji (czyli rok lub nawet 2 lata później). Jest bowiem na niej wiele ewidentnych pomyłek, na co zwróciłem uwagę już w $2015 \mathrm{r}^{10}{ }^{10}$ Te pomyłki niewątpliwie mogły powstać wskutek upływu czasu. Wreszcie mógł też Beniowski kreślić tę mapę w pewnym pośpiechu we Francji, wykonując zadanie, które w owym czasie przestało już go interesować. Zdaniem współpracującego z Fundacją im. Maurycego Beniowskiego w Nowej Soli francusko-belgijskiego badacza Jeana Marie Meskensa mapa mogła zostać wykreślona dopiero w 1773 r., gdy Beniowski po sprowadzeniu do Francji żony i syna zamieszkał w Paryżu, przy Rue Jacob 56, w szóstej dzielnicy na Saint Germains des Prés ${ }^{11}$. W tym czasie z dnia na dzień stał się uznanym bohaterem brawurowej ucieczki z zesłania (podczas gdy wielu francuskich uczestników konfederacji spędziło jeszcze całe lata na Syberii), został bywalcem salonów, a głowę zaprzątały mu pomysły założenia francuskiej kolonii na Tajwanie. Na te niedokładności niedawno zwrócił uwagę niezależnie ode mnie tajwański historyk Chuang Hung-he ${ }^{12}$.

Czy autorem odnalezionego egzemplarza mapy był sam Beniowski? Moim zdaniem - tak. Nie ma żadnych podstaw do posądzania go o to, że mógł korygować swoją mapę w oparciu o późniejsze odkrycia, np. trzeciej ekspedycji Jamesa Cooka, której rezultaty zostały opublikowane w $1784 \mathrm{r}$. w Londynie (w tym czasie Beniowski już nie był posiadaczem rękopisu z British Museum).

Poprzestając na tym krótkim wstępie, chciałbym jednocześnie uświadomić czytelnikom, że wiele się zmieniło od czasu napisania przeze mnie przed ponad 30 laty pierwszej książki o żegludze Beniowskiego ${ }^{13}$, przeciwstawiającej mój pogląd na temat jej autentyzmu szeroko wówczas rozpowszechnionym w Polsce opiniom Leona Orłowskiego, Janusza Roszki czy Stanisława Biernatta, którzy zarzucali Beniowskiemu zmyślenie dziennika swej podróży przez Pacyfik. Wtedy byłem w swoich poglądach odosobniony, podczas gdy dziś naliczyłem już około 30 książek popularnonaukowych, powstałych między 1989 a 2017 r. i traktujących w całości

10 E. Kajdański, Odkerywca cæy blagier?..., s. 35.

11 J.M. Meskens, Un episode dans la vie de Maurice Benyowsky. Sous le covert de la Fondation Maurycego Beniowskiego de Nowa Sol, Nowa Sól 2017, s. 22.

12 Chuang Hung-he, 1771, Formosa - based on Benyowsky's nautical journal, Taipei 2014. Chuang pisze: „The map of Pacific which Benyowsky had drawn for the French Foreign Minister about one year after his stay on Formosa may have not been elaborated with exactitude after such long interval".

13 E. Kajdański, Nięwyklty rejs „Św. Piotra i Pawła”, Szczecin 1989. 
lub częściowo o sprawach żeglugi Beniowskiego przez Pacyfik. Większość z nich potwierdza moje wcześniejsze wnioski o jej autentyzmie, co jest oczywiście powodem do satysfakcji. Paradoksalnie tematyka dyskusji o żegludze Beniowskiego oscyluje obecnie nie wokół jego pobytu na Morzu Beringa i u wybrzeży Alaski, czego oczekiwałem po ukazaniu się moich pierwszych książek poruszających ten temat, tylko wokół końcowych etapów podróży do Makau, omawiających żegluge u wybrzeży Japonii, wysp Liuqiu (Riukiu), Formozy i Chin. Zainteresowanie żegluga przez te obszary w kontekście rywalizacji w owym czasie o udział w handlu ze Wschodem między Hiszpanią i Holandią, później między Anglią i Francją, Stanami Zjednoczonymi i Rosją jest doskonale odzwierciedlone w tematyce Międzynarodowej konferencji naukowej „Maurice Benyowsky - eminent citizen of Europe and of the World in the light of most recent international discoveries. International scientific meeting in honor of his life anniversaries (1746-1786)", zorganizowanej 25 października 2016 r. w Bratysławie z udziałem naukowców z Austrii, Francji, Holandii, Polski, Słowacji i Węgier. Większość referatów związanych bądź z badaniami nad biografią Beniowskiego w reprezentowanych krajach, bądź z jego żegluga przez obszary północnego Pacyfiku, z zawinięciami do portów Japonii, wysp Liuqiu, Tajwanu, południowych Chin i Makau, wniosła nadspodziewanie dużo nowych informacji potwierdzających autentyzm Dziennika żeglugi, choć pojawiły się także głosy odrębne. O niektórych z tych odkryć będę chciał wspomnieć w niniejszym opracowaniu.

Mimo, wydawałoby się, bardzo mocnych dowodów na to, że Isle de Liqueur Beniowskiego faktycznie istniała, pobyt na niej załogi „Św. Piotra i Pawła” był bardzo długo negowany przez rosyjskich i europejskich autorów. Wątpliwości zaczęły się pojawiać już wkrótce po ukazaniu się pierwodruku Pamiętników, choć były one wówczas oparte tylko na porównywaniu treści dziennika z okrojoną relacją Stiepanowa (a także z relacją Riumina po publikacjach Bercha z 1821 i 1822 r.). Jako pierwszy zaczął podważać ten epizod w żeglarskiej epopei Beniowskiego Heinrich Gottfried von Bretschneider, Saksończyk, który służył w armii austriackiej i - jak twierdził - osobiście znał Beniowskiego. Nie dowierzając obfitości kokosów, bananów, pomarańczy i innych południowych owoców na tej niezamieszkanej wyspie, Bretschneider pisze jedynie, że „Stiepanow nie wspomina w swoim opisie o tym bogactwie ani jednym słowem"14, co nie było do końca prawdą. Nie znalazła się w wyciagu z jego relacji żadna wzmianka o „Wyspie Wodnej”, lecz pojawiło się w nim jednoznaczne stwierdzenie, że pierwsze spotkanie załogi statku z lądem po przebyciu upalnego obszaru na wodach Pacyfiku miało miejsce pod szerokościa $33^{\circ}$, a na tej szerokości (ściślej pod $32^{\circ} 45^{\prime}$ ) znajdowała się zgodnie z Dziennikiem żeglugi Isle de Liqueur.

14 J.G. Meusel, Vermischte Nachrichten und Bemerkungen historischen und literarischen Inhalts, Erlangen 1816, s. 111. 
Kolejny zarzut „wklejenia tu bajki o Wyspie Wodnej” upowszechnili w Londynie rosyjski dyplomata i agent - W.N. Berch oraz węgierski emigrant L.L.K. (Lajos Lewis Kropf), który z kolei bezpodstawnie sugerował, że Beniowski pomylił Wyspy Liqueio (obecnie Riukiu) z Isle de Liqueur ${ }^{15}$. Wydawca i autor komentarzy do Pamiętników z 1893, 1898 i 1904 r. Samuel Pasfield Oliver dla odmiany twierdził, że był to opis jednej z wysp Batan, znanych w XVIII w. pod nazwą wysp Bashee, choć wszystkie te przypuszczenia pozostawały w sprzeczności z Dziennikiem żeglugi. Pasfield Oliver wysnuł z nazwy wyspy Isle de Liqueur zaskakujący wniosek, twierdząc, że: „nazwa tej całkowicie fikcyjnej wyspy była nazwa nadaną przez Dampiera wyspie Bashee, od nazwy pewnego trującego likieru, powszechnie stosowanego przez krajowców"16. Skoro była fikcyjna, to nie mogła być wyspą Bashee (sic!). Dampier był angielskim żeglarzem, zaś wyspa Bashee znajdowała się w pobliżu dzisiejszej cieśniny o takiej samej nazwie, oddzielającej Wyspy Filipińskie od Tajwanu ${ }^{17}$. Ani z Dziennika żeglugi, ani z relacji Stiepanowa nie wynika, że statek dopłynął w tym czasie do Zwrotnika Raka i że go przekroczył w trakcie rejsu do Makau ${ }^{18}$. Błąd Olivera powtarzany był później jak mantra także przez polskich autorów.

Jeżeli spojrzymy na mapę Pacyfiku w jego środkowej części, to przekonamy się, że na północ od Wysp Mariańskich znajdują się liczne wyspy ciagnące się w kierunku półwyspu Izu na największej wyspie Japonii - Honshu (za tym półwyspem znajdowała się japońska stolica Edo, dzisiejsze Tokio). Są to faktycznie dwie grupy wysp: Bonin lub Ogasawara oraz Izu, często traktowane jako jeden archipelag. Nazwa Bonin pochodzi od japońskiego bu-nin - „Wyspy Bezludne”, ponieważ, gdy zostały przez Japończyków odkryte, nie były zamieszkane. Niezbyt udana próba ich zasiedlenia przez politycznych zesłańców trwała od $1721 \mathrm{r}$. Mniej więcej w samym środku tego archipelagu położona jest samotna mała wulkaniczna wysepka (ok. 6 km²) - Aogashima. Już w końcu ubiegłego wieku węgierski geograf, etnograf i badacz żeglugi Beniowskiego przez Pacyfik János Jankó wyraził pogląd, że to właśnie Aogashima została nazwana przez załogę „Św. Piotra i Pawła” Wyspą Płynu lub Wyspą Wodną ${ }^{19}$. W języku japońskim Aogashima oznacza „Zieloną Wyspę”. Była ona ostatnią z wysp leżących na wschód od Japonii, odwiedzanych sporadycznie przez Japończyków, zanim na przełomie XVI i XVII w. lord Sadayori Ogasawara

15 W.N. Berch, Pobieg grafa Beniowskogo iz Kamczatki wo Franciju, „Syn Otieczestwa” 1821, nr 28, s. 52; L.L.K [Lajos Lewis Kropf], Mauritius Augustus Benyonsky, „Notes and Querries” 1895, no. 12, s. 322-324.

16 P. Oliver, The Memoirs and Travels of Mauritius Augustus Count de Benyowsky in Siberia, Kamchatka, Japan, the Liukiu Islands and Formosa, from the Translation of his Original Manuscript (1741-1771) by William Nicholson, F.R.S., 1790, ed. Captain S. Pasfield Oliver, London 1898, s. 333.

17 Dziś wyspa Bashee wraz z kilkoma mniejszymi nosi nazwę Wysp Batan.

18 P. Oliver, The Memoirs and Travels..., s. 288.

19 J. Jankó, Grof Benyowszky Moric mint földrazi kutató. Kritikai megiegyzések Kamcsatkától Macaoig tet úyjára, Budapest 1887, s. 27. 
nie wyprawił zorganizowanej ekspedycji na dalsze wyspy, które od tego czasu noszą jego imię. Zostały one po raz pierwszy ukazane przez Japończyków na mapach jako należące do Cesarstwa Japonii w roku $1785^{20}$.

Muszę przyznać, że gdy w końcu lat 80 . przygotowywałem do druku moją pierwszą książkę o żegludze Beniowskiego pt. Nieznylkty rejs "ŚSw. Piotra i Pawła”, miałem bardzo ograniczony dostęp do informacji o wyspach Bonin ${ }^{21}$. Popełniłem wówczas błąd, może mało istotny geograficznie, lecz ważny w dochodzeniu do prawdy o żegludze Beniowskiego. Sugerując się japońską nazwa „Zielona Wyspa”, jej szerokościa geograficzna podana, jak stwierdziłem, z dużą dokładnością w Džienniku ṙeglugi oraz tym, że znajdowała się ona w samym centrum ciepłego prądu Kuro Shio (średnia temperatura zimy $-19-20^{\circ} \mathrm{C}$, lata $-29-30^{\circ} \mathrm{C}$ ), przyjąłem, że właśnie tę wyspę odwiedziła załoga „Św. Piotra i Pawła”. Wyspy Bonin i Izu nie były odwiedzane przez europejskich żeglarzy w czasie, gdy przybył tam Beniowski. Nie był ich odkrywca (choć w literaturze geograficznej używany jest często termin „ponowne odkrycie”, ,ponowny odkrywca”), ale niewatpliwie był pierwszym żeglarzem, który wylądował na jednej z tych wysp i opisał jej przyrodę. Niestety, różnorodność warzyw i owoców, o których wspomniał, a także obecność na niej drobiu, kóz i wieprzy nie sprzyjała uznaniu jego relacji za prawdziwą. Żaden z żeglarzy holenderskich nie zblizył się do wysp Bonin i Izu wcześniej na odległość mniejszą niż 6 mil morskich. W 1818 r. opis tych wysp, zatytułowany Wyspy Bunin albo Bezludne, został po raz pierwszy opublikowany we Francji, powodując zainteresowanie nimi żeglarzy i geografów ${ }^{22}$. Wyspa Aogashima, podobnie jak pobliska wyspa Hachijo, służyła niegdyś za miejsce zesłania dla niebezpiecznych przeciwników shogunów i dajmio, którym pozostawiano tam możliwości przeżycia, zezwalając na zabranie z sobą nasion warzyw oraz zwierząt domowych ${ }^{23}$.

W 1989 r. napisałem w Nieznykktym rejsie „Św. Piotra i Pawta”, że „Jeżeli przeniesiemy szerokość geograficzną z Driennika $32^{\circ} 45^{\prime} \mathrm{N}$ na dzisiejsze mapy, to wskażą nam one dokładnie wyspę Aogashima między wyspami Izu i Bonin”24. Tę samą identyfikację powtórzyłem w 1994 r. w Tajemnicy Beniowskiego $0^{25}$. Nie sprostowałem jej w wydanych 2 lata później Pamiętnikach Beniowskiego z moimi komentarzami ${ }^{26}$.

20 R. Robertson, The Bonin Islands, ,Transactions of the Asiatic Society of Japan” 1876, vol. 5, s. 111-140; L.B. Cholmondeley, The History of the Bonin Islands, London 1915; M. Stanley, Welcome to Burbs, „Discovery” 1995, no. 4, s. 47-54; R. Golsmitdt, Neu-Japan. Reisebilder aus Formosa den Ryukyuinseln, Boninisnseln, Korea und dem südmandschuischen Pachtgebiet, Berlin 1927, s. 180, 218.

21 Zob. R. Robertson, The Bonin Islands...; L.B. Cholmondeley, The History of the Bonin...

22 Ph.F. Siebold, Geographical bd Ethnographical Elucidations to the Discoveries of Meten Gerritz, Vries, Commander of the flute Castricum, A.D. 1643 in the East and North of Japan, London 1857, s. 4.

23 E. Kajdański, Beniowskei u wybrzę̇y..., s. 99-110.

24 E. Kajdański, Nieznyykty rejs..., s. 84.

25 E. Kajdański, Tajemnica Benionskiego. Odkrycia, intrygi, fatszerstwa, Warszawa 1994.

26 M. Beniowski, Pamiętniki, tłum., przedmowa i przypisy E. Kajdański, Warszawa 1996. 
Wprawdzie już w 2007 r. odkryłem, że najwcześniejszej identyfikacji „Wyspy Wodnej” jako Aogashimy dokonał Jankó ${ }^{27}$, lecz tę informację z niezależnych ode mnie powodów opublikowałem dopiero w $2015 \mathrm{r}^{28}$ Odnaleziona mapa Beniowskiego jest wiarygodnym dowodem na to, że w miarę dokładnie podawał on szerokości geograficzne. Dzisiejsza obfitość informacji o wyspach Bonin i Izu w japońskich środkach przekazu wymaga niestety ode mnie dokonania korekty tej identyfikacji, a mianowicie przyznania, że wyspą tą nie była Aogashima, tylko leżąca około $40^{\circ} \mathrm{N}$ bardziej na północ wyspa Hatijo (Hatijo-shima ${ }^{29}$. Nowych dowodów na to, niestety, jest sporo. Przytaczam je poniżej.

Aogashima jest wyspa zbyt mała (zaledwie $6 \mathrm{~km}^{2}$ ), aby mogły zaistnieć na niej wydarzenia opisane w Džienniku żeglugi. Jest to wystający na kilkaset metrów nad powierzchnią wody stożek wulkanu o bardzo stromych zboczach i braku dogodnych miejsc do kotwiczenia statku. Gdy w $1771 \mathrm{r}$. Beniowski pojawił się w pobliżu Wysp Bonin, wysepka ta wciąż była jeszcze zamieszkała przez zesłańców (w Drienniku jest ona określona jako niezamieszkała). W latach 1780-1785 doszło do trzykrotnej erupcji jej wulkanu i według japońskich przekazów zginęła wówczas blisko połowa mieszkańców z liczącej 327 osób populacji. Sąsiadująca z Aogashimą wyspa Hatijo dla odmiany spełnia wszystkie warunki znane nam z treści Driennika. Jest przede wszystkim wielokrotnie większa $\left(70 \mathrm{~km}^{2}\right)$, ma też wulkan, który po raz ostatni obudził się w roku 1606, po czym Japończycy już jej nie zasiedlali i załoga „Św. Piotra i Pawła" nie znalazła na niej śladów ludzi poza pozostawionymi zdziczałymi zwierzętami domowymi oraz bujną roślinnością z południowymi warzywami i owocami. Zwróciłem uwagę na te okoliczności już w Nieznylklym rejsie „Św. Piotra i Pawła”, a omówiłem znacznie szerzej w Tajemnicy Beniowskiego z 1994 r.

Poza tym znaczna część wyspy Hatijo jest nizinna, są tam piaszczyste plaże i głębsze zatoki, a pamiętajmy, że po zbliżeniu się do wyspy część załogi dopłynęła do lądu łodzią i przeszła kawałek wzdłuż brzegu w poszukiwaniu odpowiedniego miejsca do zakotwiczenia statku. Obydwie wyspy, Aogashima i Hatijo, są położone na tym samym południku przebiegającym przez sam środek prądu Kiro Shio i warunki klimatyczne są na nich dokładnie takie same.

Mapa Beniowskiego potwierdziła, że z Wyspy Wodnej „Św. Piotr i Paweł” skierował się wzdłuż wysp Izu do ówczesnej zatoki Owari. Jest to dzisiejsza zatoka Ise (Isio). Statek opłynął najpierw jedną z wysp Izu od północy (mogła nią być wyspa

27 J. Jankó, Grof Benyowszky..., s. 27.

28 E. Kajdański, Odkerywca çy blagier?..., s. 156.

29 Wystarczy przejrzeć w Internecie reklamy japońskich biur podróży czy organizacji turystycznych. Na Hatijo są dziś liczne ośrodki sportów wodnych (surfingu, nurkowania) z dogodnym połączeniem lotniczym ze stolicy (na wyspie zostało w tym celu zbudowane lotnisko). Aogashima też oferuje usługi turystyczne dla miłośników ekstremalnych wrażeń, ale dostać się tam można tylko helikopterem z Hatijio.

30 E. Kajdański, Niezwykety rejs..., s. 83, 84. 
Mikura), a następnie przepłynął między dwiema następnymi wyspami. Największa z tej grupy wysp na odnalezionej mapie została nazwana Isle d'Hungrie, czyli Wyspa Węgierską i przypuszczalnie była to największa wyspa archipelagu - Izu-Oshima (ponad $90 \mathrm{~km}^{2}$ ), drugą natomiast, gdzie dostrzeżono sterty rybich ości na brzegu, mogła być wyspa Miyakejima, o której wiadomo, że przez cały okres Edo była miejscem zesłań niewygodnych rywali do władzy.

Jednym z licznych powodów sporu o autentyzm Dĩiennika żeglugi jest identyfikacja zatoki, w której po raz pierwszy wylądowała w Japonii załoga „Św. Piotra i Pawła". W Pamiętnikach została ona nazwana zatoką Usilpathar. Poświęciłem jej dużo miejsca w swoich pracach ${ }^{31}$. Dodam tu tylko krótkie uzupełnienie. Na całym wschodnim wybrzeżu Japonii, między $33^{\circ}$ a $35^{\circ}$, istnieje tylko jedna zatoka, całkowicie odpowiadająca opisowi i rysunkowi Beniowskiego z Džiennika żeglugi i jest nią wspomniana zatoka Ise. Pierwszym autorem, który poprawnie ją zidentyfikował, był angielski wydawca Pamietników z roku 1893 i dalszych - kapitan Pasfield Oliver. Powołuje się on w swoich wydaniach na szwedzkiego lekarza i botanika Karla Petera Thunberga, który po zatrudnieniu się w 1775 r. w charakterze lekarza w holenderskiej Kompanii Wschodnioindyjskiej przebywał przez kilka lat w Japonii, w faktorii handlowej na sztucznej wysepce Deshimie w Nagasaki. W charakterze członka delegacji holenderskiej odbył m.in. podróż do stolicy Japonii - Yedo (Edo). Nie miałem okazji dotrzeć do dzienników Thunberga, ale Oliver cytuje jego słowa, że Beniowski życzliwie wyraża się o dobrym nastawieniu, szlachetności i gościnności narodu japońskiego w stosunku do cudzoziemców i „mówi o nim jako o jednym z nielicznych podróżników, którzy odwiedzili te n kraj Japonii”" [podkreśl. - E.K. $]^{32}$.

Pasfield Oliver przebywał przez dłuższy czas w Azji Wschodniej, m.in. w Chinach i Japonii, był zatem w stanie poprawnie zidentyfikować miejsce pierwszego przybycia „Św. Piotra i Pawła” do wybrzeży Japonii. Pisze on, że „Namgu lub Namqu jest przypuszczalnie miasteczkiem obecnie znanym jako Nagoja, którego portem jest Funekata (Adatsu), nazwana przez Beniowskiego Usilpatchar, w głębi zatoki Owari w Japonii”’33.

$\mathrm{Na}$ odnalezionej mapie Beniowskiego główna i największa wyspa Japonii - Honsiu jest ukazana pod powszechnie stosowaną wówczas nazwą - Isle de Japon. Są na niej widoczne blisko siebie cztery głęboko wcinające się w ląd zatoki: Tokijska, Sagami, Suruga i Ise. Łatwo je od siebie odróżnić, gdyż w pobliżu Zatoki Tokijskiej widzimy miniaturę zamku z podpisem Edo, natomiast w głębi zatoki Ise (Owari) uwidoczniona jest nazwa Kilingur (dzisiejszej rzeki Ise), przy której ujściu kotwiczył

\footnotetext{
31 E. Kajdański, Beniowski u wybræę̇y..., s. 103-105; idem, Niezwykety rejs..., s. 165-180; idem, Odkrywca cay blagier?...

32 P. Oliver, The Memoirs and Travels..., s. 26.

33 Ibidem, s. 16. Owari to dawna nazwa zatoki Ise.
} 
„Św. Piotr i Paweł” i gdzie znajduje się miasto Nagoya. Dokładnie do tego ujścia prowadzi na mapie przerywana linia z trasą żeglugi Beniowskiego.

Poświęciłem wiele uwagi zatoce, do której wpłynął „Św. Piotr i Paweł”, ponieważ sprawiała ona biografom Beniowskiego od samego początku duże problemy identyfikacyjne. Riumin potwierdza informację z Driennika, że Beniowski, zbliżając się do wybrzeży japońskich, powiedział załodze, by udawali Holendrów płynących do Nagasaki. O podaniu się za Holendrów wspomina również Stiepanow, stwierdzając, że holenderską flagę wywieszono, gdy znajdowali się w pobliżu (sic!) Nagasaki ${ }^{34}$.

Dyżurnym tematem do licznych dyskusji na temat żeglugi Beniowskiego wzdłuż wybrzeży Japonii, począwszy od ostatniej dekady XIX w. i nadal, jest liczba i kolejność zawinięć „Św. Piotra i Pawła” do portów japońskich - od opuszczeniu zatoki Usilpatchar w dniu 3 sierpnia 1771 r. do przybycia 10 dni później do wyspy Takasima lub Tanasima, utożsamianej z dzisiejszą Tanegashimą. W Niezwykłym rejsie „Św. Piotra i Pawta” przyjąłem za Kazimierzem Grochowskim, że pierwszy postój statku w drodze do Tanegashimy miał miejsce „na pobrzeżu półwyspu Idzu, w zatoce Misaqui" "35. Grochowski przebywał przez pewien czas w Japonii, więc wiedział, o czym pisał. Byłem już wtedy całkowicie przekonany, że podana w Drienniku żeglugi nazwa „Misaqui Iphima Kallas” dotyczyła zatoki na przylądku Shionomisaki, na południowym cyplu głównej i największej wyspy Japonii - Honsiu ${ }^{36}$, zaś Iphima Kallas była zniekształconym brzmieniem dziewiętnastowiecznego małego portu Oshimakawa. Oshima, będąca częścią tej nazwy (obecnie Kii-Oshima), to nazwa wyspy położonej niecałe $2 \mathrm{~km}$ od przylądka ${ }^{37}$.

Zawinięcie „Św. Piotra i Pawła” do dwóch (wg niektórych informacji do trzech) portów na wyspie Sikoku i związane z tymi miejscami wydarzenia były na przestrzeni dwóch stuleci przedmiotem licznych kontrowersji, ponieważ zachowało się sześć listów Beniowskiego do Holendrów w Nagasaki (i jedno pokwitowanie dotyczące otrzymanych na Kii-Oshima produktów) oraz obszerna korespondencja między władzami dwóch księstw z wyspy Sikoku a Holendrami w faktorii handlowej w Nagasaki oraz ze zwierzchnikami w Osaka i w Edo. Treść tych materiałów poza jednym z listów nie była mi wcześniej znana ${ }^{38}$. Na przestrzeni ostatnich 3 lat miałem możliwość zapoznania się także z innymi materiałami z archiwów japońskich, które

\footnotetext{
${ }^{34}$ Des Grafen Moritz. von Benjowski Behebenheitem und Reisen, von ibm selbst bwshrieben. Mir der ersten Anmerkungen und Zusatzen wie auch eimem Auszuge aus Hippolitus Stephanows russisch geschriebenem Tagebuche über seine Reise von Kamtschatka nach Makau, hrsg. J.P. Ebeling, Hamburg 1791, s. 288.

35 K. Grochowski, Polacy na Dalekim Wschodzie, Harbin 1928, s. 146, 147.

36 E. Kajdański, Nieznylkety rejs..., s. 109.

37 W j. japońskim ,wielka wyspa”. Wysp wokół Japonii o tej nazwie jest wiele (co najmniej trzy były na trasie żeglugi), stąd liczne błędy identyfikacyjne.

38 Zarówno te, jak i inne informacje z holenderskich archiwów uzyskałem dzięki uprzejmości Lamberta van der Aalsvoorta, holenderskiego znawcy historii Formozy i pobytów na niej Beniowskiego, który odwiedził mnie w Gdańsku w 2016 r.
} 
rzucają całkiem nowe światło na zawartość raportów miejscowych władz japońskich do ich zwierzchników w Osaka i Edo związanych z pobytami Beniowskiego ${ }^{39}$. Wydarzeniom w portach księstw Tosa i Awa na wyspie Sikoku i na dalszej trasie żeglugi do Tanehgashimy w dniach 5-14 sierpnia poświęciłem obszerne oddzielne opracowanie, które, mam nadzieję, niedługo ukaże się w druku.

Swoistym fenomenem było dla mnie przyjęcie w Polsce w latach 80. XX w. za dobrą monetę twierdzenia Leona Orłowskiego i Janusza Roszki, że Beniowski zmyślił swój pobyt na jednej z dzisiejszych wysp Riukiu - Amamioshimie ${ }^{40}$. Opis wyspy Amamioshima i mających na niej miejsce wydarzeń w Dzienniku żeglugi był jednym z filarów, na których oparłem swoje badania nad jego autentyzmem ${ }^{41}$. Orłowski pisał wbrew faktom, że zarówno Riumin, jak i Stiepanow „milczą o cudownej Usmay Ligon”42. Ten bezpodstawny i nieprawdziwy sąd powtarzał Roszko, pisząc, że „nie wspominają o niej słowem współtowarzysze podróży: Riumin i Stiepanow"43.

Riumin bowiem - jak na ,wyciąg”, czyli relację okrojoną z wielu istotnych wydarzeń - pisze o niej dość obszernie i jest pełen zachwytu dla przyrody wyspy, jej zasobności we wszystko, co jest potrzebne do życia, a nade wszystko dla niezwykle życzliwych i uczynnych mieszkańców, którzy „,tak dla nas byli serdeczni, jak gdyby z nami już długi czas żyli4i. Pisze:

ujrzeliśmy ziemię z prawej strony, która przedstawiała sobą sporą wyspę, otoczoną wysokimi górami i kamieniami, z lewej zaś strony też widoczna była ziemia, niewielka wyspa i doszliśmy do tej dużej wyspy już nocą (na której widoczny był ogień w różnych miejscach przez całą noc $)^{45}$.

39 M. Musil, Skutočný pribeh grófa Mórica Beňowského, Bratislava-Taipei 2017; N. Godefroy, Crossroads of Empire. The Afterlife of Maurice Benyowsky's Warning and the Race in the North Pacific (17711775) [w:] Maurice Benyowsky, eminent citizen of Europe and the World in the light of most recent discoveries. International Workshop, Bratislava 2016; L. Roberts, Shipwreaks and Flotsam. The Foreign World in Edo Period Tosa, „Monumenta Nipponica” 2015, vol. 70, no. 1.

40 Beniowski nazywa ją w Pamiętnikach Usmay Ligon. Ta podwójna nazwa wskazuje jednoznacznie na dzisiejszą wyspę Amamioshima (dawna nazwa Ooshima) w archipelagu Riukiu, Liuqiu, dawne Liqueio Portugalczyków, przypuszczalnie błędnie przepisane przez kopistę (Ligon zamiast Ligou).

41 E. Kajdański, Beniowski na wyspach Rinkiu, „Kwartalnik Historii Nauki i Techniki” 1989, nr 2, s. 819-869; idem, The Earliest Accounts of the Liqueio (Ryukyu) Islands in Eighteen Century Europe, „Actes du VI Colloque International de Sinologie Chantilly 1989. Varietes Sinologiques Nouvelle" 1995, vol. 78, s. 233-257; idem, Benyowsky on the Ryukyu Islands [w:] Maurice Benyowsky, eminent citizen...

42 L. Orłowski, Maurycy August Beniowski, Warszawa 1961, s. 105.

43 J. Roszko, Awanturnik nieśmiertelny, Katowice 1989, s. 129.

44 I. Riumin, Opisanije o razbitii russkogo goroda, red. W.N. Berch, „Siewiernyj Archiw” 1822, cz. 47 , s. 344.

45 Ibidem. 


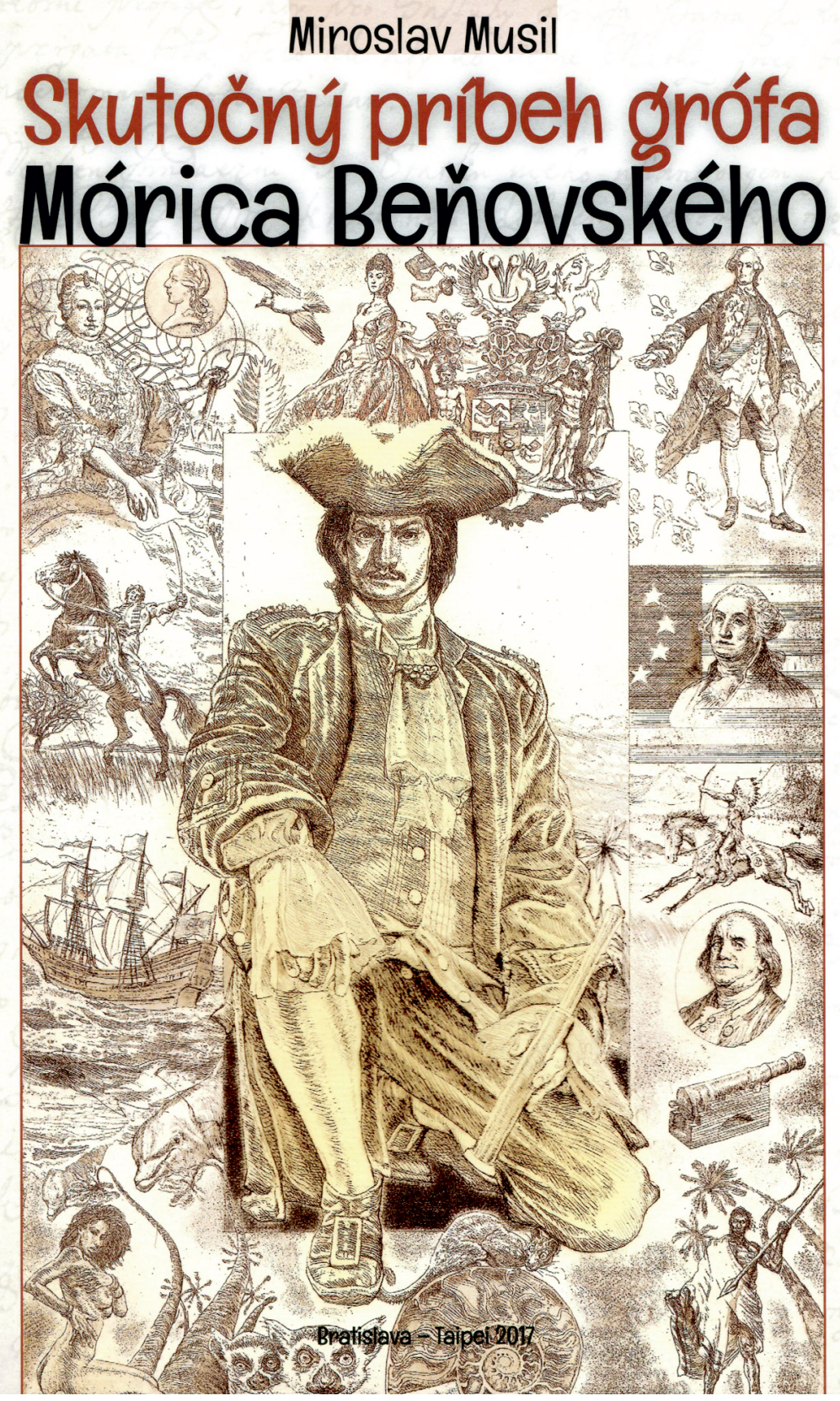

Ryc. 1. Wizerunek Beniowskiego jako żeglarza z okładki książki M. Musila, Skutočný pribeh grófa Mórica Beňowskébo (Bratislava-Taipei 2017) na podstawie jego pomnika w Werbowej 
Dokładnie tak samo opisuje miejsce przybycia Beniowski (,znalazłem się między dwiema wyspami u ujścia cieśniny"). Wspomniana w obu relacjach mała wyspa, widoczna z lewej burty statku, nosi obecnie nazwę Kikai lub Kikaigashima. Stiepanow, w odróżnieniu od Riumina, podał szerokość geograficzną wyspy, nazwanej przez niego Usmasti: $28^{\circ} \mathrm{N}^{46}$ (w Pamietnikach: $28^{\circ} 43^{\prime}$ ). Na odnalezionej mapie Beniowski umieścił Amamiosimę w archipelagu w miarę poprawnie $\left(28^{\circ} \mathrm{N}\right)$, podkreślając jej wielkość poprzez zamieszczoną obok nazwę: „Grande Usmay”.

Ze względu na otoczenie ze wszystkich stron rafami koralowymi wyspy Liuqu były bardzo niebezpieczne dla statków żaglowych, toteż nie zawijali na nią ani Holendrzy, ani Portugalczycy i pozostawały one wciąż nieznane Europejskim żeglarzom. Beniowski pozostawił $\mathrm{w}$ teczce $\mathrm{z}$ rysunkami zamieszczony później $\mathrm{w}$ pierwodruku Pamietnikón szkic zatoki, w której „Św. Piotr i Pawel” wpadł na przybrzeżne skały i na której brzegu wylądowała załoga. Muszę przyznać, że gdy w 1992 r. przygotowywałem do druku Tajemnice Beniowskiego, zidentyfikowałem ja jako zatokę Kasari (Kasari-wan), w północnej części wyspy ${ }^{47}$. Wydawało mi się wówczas, że skoro „Św. Piotr i Paweł” płynął z północy na południe, do wypadku tego powinno dojść przy podchodzeniu do wyspy od północy. Sugerowałem też, że szkic ten został odwrócony o $180^{\circ}$ przez wydawców pierwodruku. Odnaleziona mapa Beniowskiego pozwoliła na sprostowanie tej - jak się obecnie okazało - błędnej hipotezy. Z ukazanej na mapie trasy rejsu wynika niewațliwie, że statek minął północną część wyspy i wpadł na przybrzeżne rafy na jej wschodnim brzegu, w miejscu, gdzie znajduje się zatoka Ishu (Ishu-wan), bardzo podobna swoim kształtem do zatoki Kasari. Jeżeli porównamy położenie tej zatoki z dokładną japońską mapa Amamioshimy ${ }^{48}$, z łatwością dostrzeżemy szczegóły podane w Drienniku ̇̇eglugi, a mianowicie: skałę, o którą uderzyła jola (mała lekka łódź żaglowa) w południowej części zatoki i miejsce, w którym statek został wyrzucony na piaszczystą mieliznę, zatokę, którą trzeba było przeciąć, aby odkryć ujście rzeki, gdzie krajowcy zakotwiczyli szalupę w drodze do grobu jezuity Dzignaro i samą rzekę, wreszcie szczyt, na którym zgodnie z Driennikiem ṙeglugi grób ten miał się znajdować. Poprawione i uzupełnione informacje o pobycie Beniowskiego na Amamioshimie przedstawiłem na wspomnianej konferencji w Bratysławie w październiku 2016 r. ${ }^{49}$

Już pierwszy wydawca Pamietników, William Nicholson, był przekonany, że wyspa odwiedzona przez Beniowskiego należała do archipelagu Riukiu. Również profesor Ebeling, wydawca niemieckiego wydania z roku 1791, podejrzewał, że Usmay Ligon Beniowskiego i Usmasti Stiepanowa to nazwy tej samej wyspy. W przypisach

46 Des Grafen Moritz, von Benjowski Behebenheitem und Reisen..., s. 290.

47 E. Kajdański, Tajemnica Beniowskiego..., s. 248.

48 Byłem w stanie operować dokładnymi współrzędnymi dzięki uprzejmości Teruo Matsumoto z Warszawy, który przywiózł mi z Japonii szczegółowe mapy Japonii i wysp Riukiu, choć nie uchroniło mnie to wówczas od błędnej identyfikacji zatoki, w której statek został wyrzucony na mieliznę

49 E. Kajdanski, Benyowsky on the Ryukyu... 
do relacji Stiepanowa wysunął nawet słuszne przypuszczenie, że Ligon w Pamiętnikach mogło być błędem w rękopisie lub w angielskim pierwodruku i że mogła to być zniekształcona nazwa Liqueio ${ }^{50}$. Natomiast Usmay czy Usmasti powinno jego

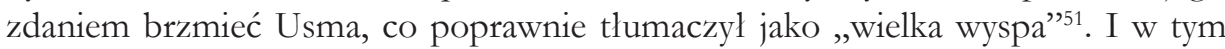
miejscu Ebeling pomylił się: Liqueio Grande nazywali Portugalczycy Okinawę, zaś Usmay Ligon była w tym archipelagu druga co do wielkości. Jej chińska nazwa brzmiała Dadao lub Yangmei Dadao, japońska - Oshima lub Amamioshima. W XVIII w. wyspy tego archipelagu były jeszcze niezależne.

W połowie XIX w. znany badacz Japonii Philipp Franz Siebold potwierdził poprawną identyfikację Usmay Ligon Beniowskiego przez braci Ebelingów (1791) jako największej z północnych wysp Riukiu - Amamioshimy (1852 r.). Siebold użył tej samej potocznej nazwy co Ebeling, tj. Ohosima, i nie miał ani krzty wattpliwości, że Beniowski był pierwszym i jedynym w owych czasach żeglarzem, który zdołał stanąć na kotwicy u jej skalistych brzegów ${ }^{52}$. Za jedną z wysp Riukiu uznał ją także wspomniany już kapitan Pasfield Oliver, który umieścił nawet te wyspy w tytule książki jako odwiedzone przez Beniowskiego ${ }^{53}$. Zainteresowanych pobytem załogi „Św. Piotra i Pawła” na tej wyspie odsyłam do moich publikacji ${ }^{54}$. W tym miejscu dodam tylko, że po usunięciu przeze mnie popełnionego podczas identyfikacji zatoki błędu (z Kasari-wan na Ishu-wan $)^{55}$ obecność załogi w tym miejscu wyspy została naocznie potwierdzona ${ }^{56}$.

Zgodnie z Pamiętnikami współtowarzysze Beniowskiego prosili go, by skierował się ku wyspie Formoza, o której informację znaleźli w Podróży lorda Ansona. Admirał Anson opłynął południowy cypel Tajwanu i w relacji z jego podróży znalazły się wzmianki o tej wyspie, co spowodowało, że Beniowski zdecydował się skierować tam statek. Być może fakt ten zadecydował, że na przestrzeni 250 lat, które upłynęły od tamtych wydarzeń, badacze żeglugi Beniowskiego poszukiwali miejsc kotwiczeń

50 Zniekształcenie chińskiej nazwy tych wysp, która później była przeważnie w europejskich publikacjach pisana jako Liukiu (dziś Liuqiu).

51 E. Kajdański, Benyowsky on the Ryukyu...

52 Ph.F. Siebold, Nippon, Leyden 1832, s. 66. Siebold pisał: „Seine nachrichten von der Insel Ohosima, die grösste der nördlischen Liukiu-Inseln, sind die einzigen, welche wir noch von einem europäischen Seefahrer davon erhalten haben".

53 Pełen tytul w tym wydaniu brzmi: The Memoirs and Travels of Mauritius Augustus Count de Benyonsky in Siberia, Kamchatka, Japan, the Linkiu Islands and Formosa, from the Translation of his Original Manuscript (1741-1771) by William Nicholson, F.R.S., 1790, ed. Captain S. Pasfield Oliver, London 1898.

54 E. Kajdański, Benionski na wyspach...; idem, The Earliest Accounts...; idem, Benyowsky on the Ryukyu...

55 E. Kajdański, Odkrywca cæy blagier?..., s. 200-211. Nową interpretację związaną z wyspa Amamioshima przedstawiłem również w referacie na międzynarodowej konferencji w Bratysławie pt. Benyowsky on the Ryukyu Islands.

56 Dokonał tego polski doktorant z Uniwersytetu Ryukańskiego, Szymon Greżuk w 2017 r., znajdując wiele śladów pobytu tam zarówno wymienionego w Dżienniku żeglugi portugalskiego jezuity Dzignaro, jak i załogi statku Beniowskiego. Podaję na podstawie informacji uzyskanej bezpośrednio od S. Greżuka. 
„Św. Piotra i Pawła” na całym wschodnim wybrzeżu Tajwanu - od dzisiejszego portu Dagankou na południu do Keelevan przy ujściu rzeki Dongshan, w zasięgu Wysp Żółwich na północy. Odkrycie mapy Beniowskiego nie przyniosło jednak jednoznacznej odpowiedzi na pytanie, do jakich dwóch (a może i trzech) miejsc i w jakiej kolejności przybijał jego statek. Na odnalezionej mapie południowy kurs statku został zmieniony i prowadzi na zachód, w kierunku wschodniego wybrzeża Tajwanu, mniej więcej na wysokości Dagankou, gdzie wskazane jest miejsce postoju, dalsza jego trasa prowadzi na północ, zaś następny postój został ukazany już w środkowej części wybrzeża, na wysokości Hualian. Brakuje niestety jakiejkolwiek wskazówki, że zgodnie z Driennikiem żeglugi statek popłynął jeszcze dalej na północ, w kierunku Suao i Keelevan. Na mapie „Św. Piotr i Paweł” opływa Wyspy Żółwie od południa, podczas gdy w Dřienniku mamy informację, że znajdował się nieco dalej na północy i dlatego przepłynął między tymi wyspami.

Jak zatem było naprawdę? Wróćmy na chwilę do momentu pierwszego (w mojej interpretacji) zbliżenia się statku do miejsca, w którym załoga zdecydowała się wyrzucić kotwicę. W dniach 25 i 26 sierpnia Beniowski odnotował działanie bardzo silnego prądu z południa, który utrudniał przybicie do brzegu. Był to ciepły prąd morski płynący wzdłuż wschodnich wybrzeży, nazwany później Prądem Formozańskim. Statek został zacumowany w niewielkiej zatoce 26 sierpnia. Riumin także pisze, że z powodu przeciwnego prądu mieli trudności z przybiciem do brzegu. Ostatnia szerokość geograficzna, jaką dysponujemy w Drienniku żeghlugi przed lądowaniem na Formozie, wynosi $23^{\circ} 18^{\prime} \mathrm{N}$, ale wiemy, że przez następne 2 dni prąd znosił statek na północ. Gdy 5 lat później w Londynie podejmowano decyzję o wysłaniu angielskiego poselstwa lorda Macartneya do Pekinu, dowódca ekspedycji, kapitan Gower, otrzymał instrukcję zobowiazzująca go do objęcia ,trasa podróży wyszczególnionej wcześniej wschodniej części wyspy Formozy, która, jak się mówi, nie należy do Chińczyków"s7. Jest to oczywista aluzja do pobytu Beniowskiego na Tajwanie i choć instrukcja nie wymieniała jego nazwiska, on jeden był w tej wschodniej części i informował o jej niezależności od Chin.

W 1795 r. została wysłana na Pacyfik kolejna angielska ekspedycja pod dowództwem W.R. Broughtona, który próbował znaleźć na wschodnim wybrzeżu Tajwanu miejsce lądowania Beniowskiego. O tym, że poszukiwał bezskutecznie zatoki przy ujściu rzeki i także natrafił na silny prąd z południa, wiemy z jego relacji. Napisał bowiem w swoim dzienniku w roku 1796:

Nasza szerokość według szacunku wynosiła 2312', jednakże oddziaływający wciąż prąd powodował, że nasze położenie powinno było znajdować się bardziej na północ. Mówi się, że hrabia Beniowski znalazł przystań w tej części wybrzeża, ale my nie dostrzegliśmy niczego, co by na nią wskazywało ${ }^{58}$.

57 G. Staunton, An Authentic Account of an Embassy from the King of England to the Great Emperor of China, $2^{\text {nd }}$ ed., London 1798, s. 573.

58 W.R. Broughton, A Voyage of Discovery to the North Pacific Ocean, London 1804, s. 187. 
Wskutek ulewnego deszczu Broughton nie dostrzegł jednak zatoki, zawrócił na wschód i oddalił się od wyspy.

Wschodnie wybrzeże Tajwanu jest słabo urzeźbione i w związku z tym wydawało mi się, że znalazłem zatokę, do której statek został wprowadzony. Na mapie z 1725 r., sumującej ponad stuletnie doświadczenie Holendrów na tych obszarach, w środkowej części wybrzeża została uwidoczniona zatoka z przylądkiem nazwanym De Hoek van Penimbos $^{59}$. Ukazana jest tam także wspomniana przez Beniowskiego mała wysepka przy przylądku, rzeka i miasteczko lub wieś o nazwie Penimbos. Porównując tę mape ze współczesnymi mapami Tajwanu, doszedłem do wniosku, że wpadająca do zatoki rzeka nosi obecnie nazwę Hualianxi, w której ujściu znajduje się dziś port Hualian. Z chińskich źródeł wiadomo, że w końcu XVIII w. było tu osiedle zwane po chińsku Hualianting. Te właśnie chińskie nazwy, w formie nieco zniekształconej, znalazły się również w Drienniku Beniowskiego. Wymienia on bowiem prowincję na wschodzie Tajwanu - Hawangsin (Hualianting) oraz rzekę o nazwie Halawith (Hualianxi). Poza tym pisze, że stanęli na kotwicy „w pobliżu rafy w widoku Formozy, wydającej się być bardzo wysokim lądem [podkreśl. - E.K.]" ${ }^{0}$. Rafa ta, niewielka wysepka w pobliżu brzegu, została uwidoczniona na wspomnianej holenderskiej mapie Formozy. Nie były to jedyne argumenty przemawiające za tym, że to właśnie Hualanting mógł być miejscem pierwszego zakotwiczenia „Św. Piotra i Pawła”. Według F.A. Todera w tym miejscu przebiegała granica między „,dzikimi” aborygenami (słynnymi „łowcami głów” nazywanymi przez Riumina Indianami) a ich „cywilizowanymi” sąsiadami. Żaden badacz tego tajwańskiego epizodu żeglugi nie kwestionuje faktu, że część załogi, która wyszła z łodzi na brzeg, szybko znalazła wpadający do rzeki potok, gdzie zaopatrzyła się w słodką wodę i przy którym się kąpała, gdy została zaatakowana przez „dzikich”. Identyfikacje dokonane przeze mnie w 1988 r., tj. jeszcze przed publikacja książki Niezrnykly rejs „Św. Piotra i Pawla”, stały się przedmiotem międzynarodowych polemik 30 lat później.

Informacje Beniowskiego o wschodnim wybrzeżu Tajwanu, zawarte w Drienniku $\dot{z}$ eglugi, zostały bardzo poważnie potraktowane przez władze francuskie oraz angielskie. Admiralicja francuska zaleciła ich sprawdzenie ekspedycji La Perouse’a, wysłanej na północny Pacyfik w roku 1785. La Perouse, jeśli wierzyć Broughtonowi, zrezygnował z przybicia do Tajwanu, gdy doszły do niego wieści z Makau, że w tym czasie wybuchło tam jedno $z$ najgwałtowniejszych $w$ historii wyspy powstań przeciw władzom mandżurskim. Ów Francuz miał dowiedzieć się o tym wcześniej od wyspiarzy, którzy na swoich łodziach podpłynęli do statku, gdy ten zbliżył się do brzegu.

Holendrzy niechętnie dzielili się z rywalami informacjami, jakie zdobywali w toku swoich podróży, ale nawet oni dobrze znali jedynie zachodnie wybrzeże Tajwanu, za-

59 F. Valentin, Oud en Nieun Oost-Indien, Dodrecht - Amsterdam 1726; L. van der Aalsvoort, Fuermosha jianwenlu. 16,17,18 shiji [Informacje o Formozie XVI, XVI, XVIII w.], Taipei 2012.

60 M. Beniowski, Pamiętniki..., s. 375. 
siedlone stosunkowo wcześnie przez wychodźców z południowych Chin. Mieli tu w XVII w. dwa swoje forty: Providentia i Zeelandia, zanim nie zostali przepędzeni przez chińskiego patriotę i pirata w jednej osobie, znanego w Europie pod imieniem Koksinga ${ }^{61}$. Miroslav Musil, powołując się na pracę francuskiej autorki Noemi Godefroy, zwraca uwagę, że w celu odstraszenia konkurencji Holendrzy rozpowszechniali wieści o okrucieństwach Japończyków i aborygenów wschodniego wybrzeża Formozy ${ }^{62}$. Najnowsze badania potwierdzają także to, że Holendrzy w XVII i XVIII w. bali się przybijać do wschodniego wybrzeża Tajwanu po masakrach dokonanych przez tubylców na marynarzach i że ich wiedza o tym wybrzeżu była oparta na szkicach wykonywanych z pewnej odległości od lądu i na sporadycznych informacjach uzyskanych od przepływających na swoich łodziach w pobliżu statków wyspiarzy ${ }^{63}$. Na dobrą sprawę bardziej szczegółowa wiedza o tubylcach zamieszkujących wyspę dotarła do Europy dopiero w końcu XIX w., po zajęciu Tajwanu przez Japończyków. Pierwsze pewniejsze wiadomości o nich zebrał japoński uczony, profesor Ino. Czytelnicy europejscy i amerykańscy mogli zapoznać się z nimi także z prac George’a Taylora i Jamesa W. Davidsona ${ }^{64}$.

Pomijam w tym opracowaniu opis wydarzeń, do których doszło w czasie pobytu załogi „Św. Piotra i Pawła” na wyspie, skupiając się głównie na zgodności lub niezgodności miejsc kotwiczenia z odnalezioną mapa Beniowskiego. Z dostępnych mi źródeł wynikało, że środkową część wschodniego wybrzeża wyspy zamieszkiwała grupa plemion znanych dziś pod wspólną nazwą Atayal ${ }^{65}$. Byli to przybysze należący do rasy malajskiej, pod względem cywilizacyjnym bardzo słabo rozwinięci. Utrzymywało się wówczas wśród Atayalów niewolnictwo, kobiety zaś brały udział w walkach na równi z mężczyznami, na co zwrócił uwagę już Beniowski, a co późniejsi badacze uznali za przeżytek matriarchatu. Byli oni ponadto zagorzałymi „łowcami głów”. Głowy zabitych wrogów ofiarowywano przodkom wraz z modłami o urodzaj. Co więcej, uznawano je za dowód męstwa i waleczności tych, którzy je zdobyli, a to decydowało o ich wpływie i randze w społeczności tubylców. Japoński profesor Ino wspominał, że Atayalowie byli niezwykle podstępni, a obłudy i nieszczerości wobec sąsiadów nie traktowano tu jako czegoś negatywnego, przeciwnie - jako wielką zaletę, zyskująca

${ }^{61}$ W Chinach jest znany pod imieniem Zheng Chenggonga.

${ }^{62}$ M. Musil, Skutočný pribeh grófa...; N. Godefroy, Crossroads of Empire...

${ }_{63}$ M. Musil, Skutočný pribeh grófa...

${ }^{64}$ G. Taylor, Aborigines of Formosa, „The China Reviev” 1886, no. 14; G. Taylor, Formosa: Characteristic traits of the island and its aboriginal inhabitants, „Proceedings of the Royal Geographical Society and Monthly Record" 1889; J.W. Davidson, The Island of Formosa, past and present. History, people, resources and commercial prospects, London 1903, wyd. 2, Oxford 1988. Taylor był latarnikiem na Peskadorach oraz na Przylądku Południowym Tajwanu i potrafił zyskać zaufanie tubylców, głównie z plemienia Paiwan, dlatego jego informacje były przez późniejszych badaczy uważane za wiarygodne i dokładne.

${ }^{65}$ J.W. Davidson, The Island of Formosa...; F.A. Toder, Tajwan i jego istorija (XIX w.), Moskwa 1978. 
powszechne uznanie ${ }^{66}$. Z Atayalami mieli sąsiadować inni niepodlegli aborygeni, nazywani Vonum (dziś Bunun) i Ami (dziś Ameisi). Ci pierwsi mieli zamieszkiwać tereny górskie w głębi wyspy i również polować na głowy wrogów, choć byli mniej agresywni od Atayalów. Również Ami byli niebezpieczni dla żeglarzy, którzy określali ten lud jako „dziki”. Od północy natomiast z Atayalami sąsiadowały plemiona zwane Pepo (dziś Seliq), jak twierdzono, pochodzenia polinezyjskiego i o znacznie łagodniejszym usposobieniu od swoich sąsiadów. W XVII w. Pepo zaczęli handlować z Holendrami, później zaś trafili pod wpływy Chińczyków kolonizujących północną część wyspy, zasymilowali się z nimi i przeważnie zniknęli z etnograficznej mapy Tajwanu.

Kiedy „dzicy” po raz pierwszy zaatakowali członków załogi Beniowskiego, ten zdecydował, by opuścić zatokę i popłynąć nieco bardziej na północ. Przyjąłem, choć dziś wielu badaczy ma co do tego spore wątpliwości, częściowo słuszne, że ten drugi postój miał miejsce w pobliżu obecnego miasta Xincheng, kilka mil bardziej na północ. Zgodnie z Dziennikiem tutejsi mieszkańcy zachowywali się pokojowo, przychodzili pod statek ,zz drobiem, ryżem, trzciną cukrowa, wieprzkami, pomarańczami i innymi owocami, które wymieniali u nas na igły, szpilki i inne drobiazgi”. Podobnie opisywał przyjęcie w tym drugim miejscu Riumin:

I tak dowiedzieliśmy się, że wyspa ta to Formoza (po portugalsku - przepiękna) i nocowaliśmy w tej przystani, rano zaś (...) przybyli pod statek na łodziach Indianie, którzy przywieźli z sobą różne dobre owoce, a najwięcej ananasów. Te ananasy są u nich bardzo duże i smaczne. Przywieźli także kury, świnie i jakiś napój zrobiony z prosa, podobny do mleka, który ma smak słodkawy. I tak ci Indianie z nami handlowali różnymi drobiazgami. Na igły, jedwab, skrawki jedwabnych materiałów, na tasiemki i inne wymienialiśmy u nich różne owoce i inne. $Z$ nimi zaś były ich żony i dzieci $(. . .)^{67}$.

Opis dalszych wydarzeń na Tajwanie, które doprowadziły do śmierci z rąk krajowców trzech towarzyszy Beniowskiego, różni się w Pamiętnikach od tych z relacji Riumina, ale za to bliższy jest ich przedstawieniu przez Stiepanowa. Zarówno Riumin, jak i Stiepanow potwierdzaja okoliczności śmierci Panowa, Popowa i Łoginowa z rąk tubylców, gdy udali się po wodę do pobliskiego potoku. Beniowski pisze, że jego towarzysze dokonali w odwecie straszliwej rzezi i był zmuszony zagrozić, że będzie do nich strzelał, jeżeli będą kontynuowali masakrę. O tym, co wydarzyło się później na wyspie, czyli o informacjach otrzymanych od zbiegłego z Manili Hiszpana, poznaniu generała Baminiego i księcia Huapy, o pomocy udzielonej dzięki posiadanym muszkietom i działom księciu Huapie w walce z jego przeciwnikiem Huapusinga, pisałem w dwóch moich książkach, do których odsyłam wszystkich zainteresowanych tym tematem ${ }^{68}$.

\footnotetext{
${ }^{66}$ J.W. Davidson, The Island of Formosa...

${ }_{67}$ I. Riumin, Opisanije o razbitii..., s. 349.

68 E. Kajdański, Tajemnica Beniowskiego..., s. 365-289; idem, Odkrywca cay blagier?..., s. 214-231.
} 
Odnaleziona mapa Beniowskiego umożliwia wyjaśnienie przynajmniej niektórych wątpliwości dotyczących dwóch lądowań na wschodnim wybrzeżu, co uwzględniają także autorzy krytycznie nastawieni do informacji z Dziennika żeglugi ${ }^{69}$. Gdy oddawałem do druku Niezuylkły rejs „Św. Piotra i Pawła” w 1988 r., byłem w posiadaniu kserokopii książki M. Shigeo i N. Jirou, w której Hualian był zaznaczony jako jedno z możliwych miejsc pierwszego lądowania. Dwoma innymi były Dagankou na południe od Hualian oraz Suao na północ od tej miejscowości. Wówczas na podstawie kilku przesłanek zidentyfikowałem miejsce pierwszego cumowania jako Hualian. Sugerowały to chińskie nazwy podane przez Beniowskiego, zgadzały się szerokości geograficzne, przekonywała do tego holenderska mapa z 1726 r. W Drienniku żeglugi Beniowski wspomniał, że przy pierwszym lądowaniu weszli do zatoki, omijając od północy wysoką skalistą wysepkę i tam napadli na jego ludzi wyspiarze. Na domniemane drugie kotwiczenie wytypowałem Xincheng (Hsincheng w publikacjach tajwańskich), ponieważ uwzględniłem informację z Driennika (i z relacji Broughtona) o bardzo silnym prądzie z południa, który zniósł statek daleko na północ. Z moich obliczeń wynikało, że, dryfując, powinni byli znaleźć się nazajutrz w pobliżu Xinchengu.

Gdy po 5 latach kończyłem Tajemnice Beniowskiego, znalazłem w Drienniku przeoczone wcześniej następujące stwierdzenie:

Uwaga: Muszę tu zwrócić uwagę, że odkryłem w tym sezonie gwałtowny prąd wzdłuż wyspy Formoza, który znosił statek z prędkością 1 i 1/4 league na godzinę, jednak zaobserwowałem, że prąd zmuszał statek do naśladowania wszystkich wygięć wybrzeża i utrzymywał nas zawsze w jednakowej odległości od niego.

Podliczyłem jeszcze raz liczbę godzin, jakie upłynęły między obydwoma lądowaniami i stwierdziłem, że w tym czasie statek mógł przebyć odległość dzieląca Hualian od Suao. Właśnie Suao jest obecnie przeważnie wymieniane jako miejsce pierwszego kotwiczenia. Beniowski rzeczywiście zaznaczył na mapie blisko niego miejsce postoju odpowiadające niewielkiej zatoczce przy miasteczku portowym Suao, jednak nie było to pierwsze lądowanie. Na dowód, że się nie myliłem, pisząc o Hualianie, przywołam kilka dodatkowych argumentów.

Zbliżając się do wschodniego wybrzeża wyspy, Beniowski zanotował, że wydawała się ona bardzo wysokim lądem i sporządził jego szkic (Nicholson nie zamieścił go jednak w pierwodruku). Takie wysokie góry charakteryzują środkową część tego wybrzeża, gdzie znajduje się Hualian. W części północnej, gdzie położone jest Suao, teren stopniowo się obniża i przechodzi w nizinny, dlatego obszar wokół

\footnotetext{
69 L. van der Aalsvoort, Benyowsky on Formosa [w:] Maurice Benyowsky, emitent citizen...; M. Musil, The Crucial Contribution by Maurice Benyowsky to Formosa's Perception in Europe in $18^{\text {th }}$ Century [w:] Maurice Benyowsky, emitent citizen...; N. Godefroy, Benyowsky; the Connection between France and Japan [w:] Maurice Benyowsky, emitent citizen...
} 
Suao, otoczony niskimi wzgórzami, nie mógł być miejscem pierwszego lądowania ${ }^{70}$. Jestem też przekonany, że moja opinia w kwestii trasy żeglugi wzdłuż wschodnich wybrzeży Tajwanu jest zgodna z nowymi informacjami o rozmieszczeniu w XVII w. poszczególnych społeczności aborygenów ${ }^{71}$. Mapa opublikowana przez Todera bardzo różni się od późniejszych ustaleń Henrietty Henderson i od zaktualizowanych map upublicznionych przez powołane do tego tajwańskie instytucje ${ }^{72}$. Został na nich skorygowany obszar zajmowany przez Atayalów w XVIII w. W zapisie z 28 sierpnia w Dżienniku żeglugi Beniowski nie wymienił z nazwy aborygenów, którzy napadli na jego ludzi przy pierwszym lądowaniu, pozostawiając puste miejsce w rękopisie ${ }^{73}$, ale już 2 dni później (30 sierpnia) po śmierci trzech członków załogi wspomina o „okrucieństwie dwóch narodów wobec moich ludzi”. Z mapy ukazujacej rozmieszczenia społeczności aborygenów w Museum of Formosan Aborigines wynika, że Indianami, którzy napadli na część załogi podczas pierwszego postoju, nie byli Atayalowie tylko Ami (Ameisi), będący także „łowcami głów”. Z Atayalami załoga spotkała się dopiero w drugim miejscu postoju (w Suao), gdyż tylko na tym obszarze mieli oni pod swoją władzą niewielki korytarz z dostępem do morza.

I jeszcze jedna ciekawostka dotycząca kierunków zainteresowania współczesnych badaczy, tym razem z dziedziny historii gospodarczej. Otóż okazało się, że wyśmiewane kiedyś informacje z Džiennika o obfitości złota na północy Tajwanu i o otrzymaniu przez Beniowskiego kilku kilogramów złota w ramach wdzięczności za wsparcie Huapy w jego konflikcie z Huapusinga znalazły potwierdzenie w pracach współczesnych badaczy. Jest to istotnym dowodem świadczącym o autentyzmie opisu wydarzeń na wyspie. Gdyby bowiem nie obecność wśród krajowców Hiszpana i jego znajomość formozańskich realiów, to w jaki sposób mogłyby znaleźć się w Drienniku żeglugi informacje o Formozie, uznane dziś bez zastrzeżeń za najwcześniejsze w Europie. Być może właśnie te wiadomości o złocie zaważyły na wysłaniu na wschodnie wybrzeże statków La Perouse'a, Gowera i Broughtona. Nawet sama Katarzyna II, planując wyprawę na Formozę z udziałem gdańszczanina Jerzego Forstera, nie zapomniała o tajwańskim złocie. Caryca w swoim pamiętniku wspomniała o Beniowskim i o jednym z jego współtowarzyszy - pułkowniku Baturinie, którego zesłała na Kamczatkę za próbę ucieczki z najbardziej strzeżonego więzienia w cesarstwie - Twierdzy Szlisselburskiej. Wzmianka ta dotyczyła złota rzekomo zrabowanego przez Beniowskiego

${ }^{70}$ Miroslav Musil zamieścił w swej książce (Skutočný pribeh..., s. 199) zdjęcie okolic Suao, będące tego najlepszym dowodem.

71 H. Harrison, Natives of Formosa. British Reports on Taiowan Indigenous People, 1650-1950, Taipei 2001.

${ }^{72}$ Mapa z aktualnie przyjmowanym rozmieszczeniem grup aborygenów Formozy jest m.in. eksponowana w Museum of Formosan Aborigines w Taipei. Zamieścił ją w swojej ostatniej książce M. Musil (Skutočný pribeh..., s. 55).

73 Podałem wówczas w przypisie, że przypuszczalnie nazwa ta brzmiała „Atayal”. M. Beniowski, Pamietniki..., rozdz. X, przyp. 19. 


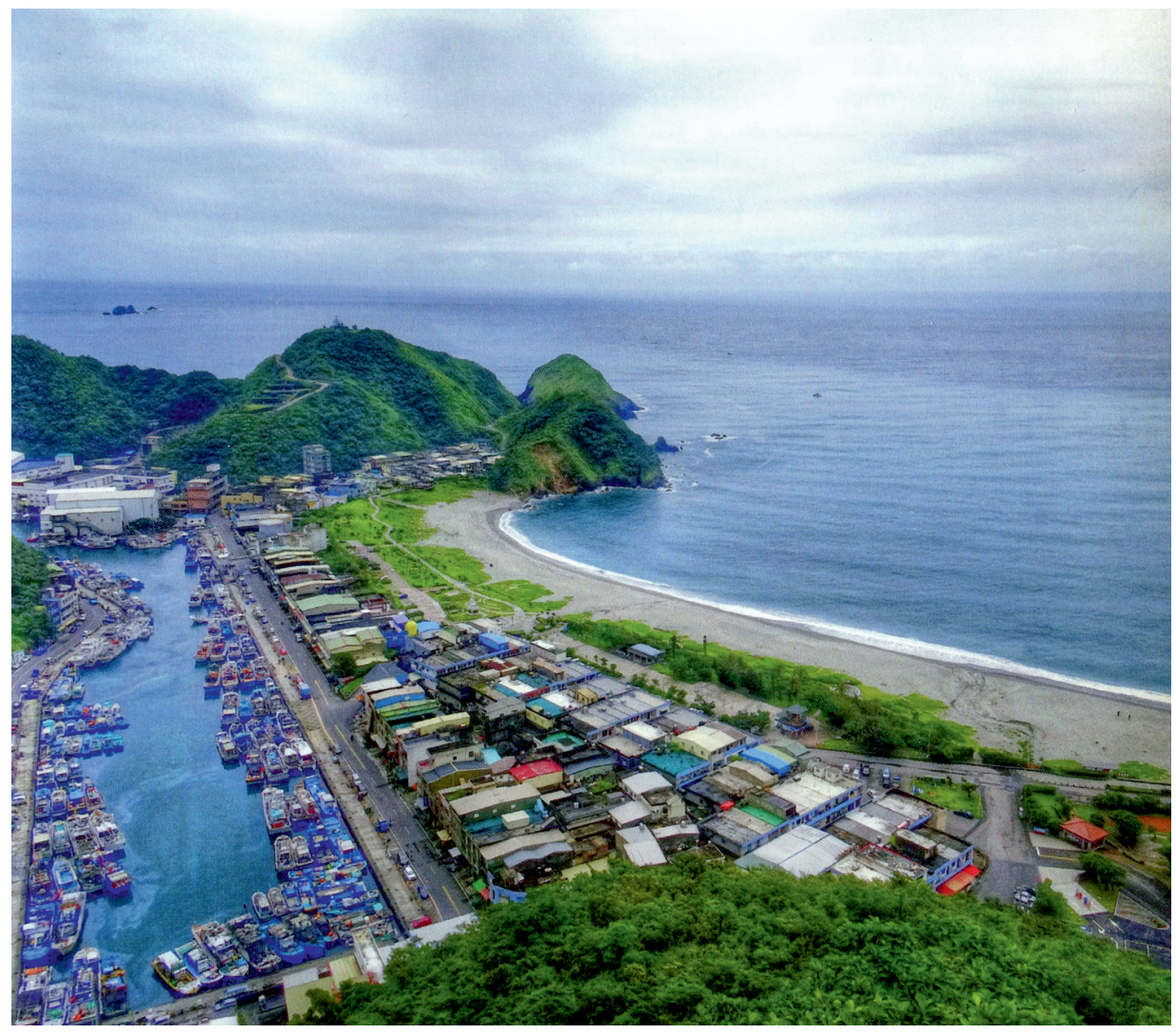

Ryc. 2. Suao na wschodnim wybrzeżu Tajwanu, w centrum przylądek z Driennika ṙeglugi Beniowskiego (fot. M. Musilová)

Źródło: M. Musil, Skutočný pribeh grófa Mórica Beñowského, Bratislava-Taipei 2017, s. 199

na Tajwanie ${ }^{74}$. Skąd Katarzyna II mogła wiedzieć o złocie? Czy z Pamiętnikón (nigdy w Rosji niewydanych) otrzymanych od zaproszonego przez nią do Rosji Jerzego Forstera, uczestnika ekspedycji Cooka i tłumacza Pamiętników na niemiecki, czy też może z nieopublikowanych nigdy w całości relacji Riumina i Stiepanowa?

Ostatni etap podróży Beniowskiego opisany w Dżienniku żeglugi jest w ogólnych zarysach zgodny z tym, co możemy zobaczyć na jego mapie. Pewne rozbieżności wynikają nie ze złej woli autora, o co był tak często posądzany, tylko z niedokładności map, z których korzystał, bądź też niefrasobliwości, z jaką zaznaczał trasę swojej żeglugi. Wysp wokół Tajwanu jest dużo i część z nich jest uwidoczniona na jego mapie, choć wydaje się, że przynajmniej w dwóch przypadkach poprowadził tę trasę nieco inaczej,

${ }^{74}$ Pamiętniki cesarzowej Kataryyny II przez niq sama spisane, z fr. przeł. E. Siemaszkiewicz, wstęp i przypisy A. Serczyk, Kraków 1980, s. 90-91. 
niż to było w rzeczywistości. Opuszczając wschodnie wybrzeże wyspy 12 września, skierował statek na północ, ,aby okrążyć najbardziej na północ wysunięty cypel wyspy Formoza" i w tym celu musiał przejść między dwiema wyspami wykreślonymi na mapie, o czym pisze w Dzienniku żeglugi. Postapił tak, aby potem opłynać wokół północnego cypla Formozy, noszącego dziś nazwę Fugujiao ${ }^{75}$. Dwie wyspy, między którymi lub obok których przepłynął, noszą dziś nazwę Wysp Żółwich ${ }^{76}$. Po okrążeniu przylądka Fugujiao statek popłynął na południowy zachód (co pokazane jest także na mapie), kierując się do Cieśniny Tajwańskiej. Tam natknął się na wysepki noszące dziś nazwę Nanjidao (pokazane na trasie rejsu na mapie). Kiedyś wyspy te były zaliczane do Peskadorów (Penghu Liedao). Pod datami 14 i 15 września Beniowski zanotował, że zaobserwowano bardzo silny prąd z północy na południe. Statek dostał się w tym czasie pod wpływ zimnego Prądu Przymorskiego, płynącego z Morza Ochockiego wzdłuż wybrzeży Kraju Przymorskiego i Korei w kierunku Cieśniny Tajwańskiej.

Dnia 15 września Beniowski wynajął dwóch chińskich pilotów, którzy mieli poprowadzić statek do Makau. Po drodze zaproponowali mu, aby wpłynąć do pobliskiego portu Tanajou, gdzie miał rządzić dobry mandaryn, w odróżnieniu od złego mandaryna w porcie Hopchin („Mandarin hopchin malas, mandarin tanajou bon bon malto bon”). Tym zniekształconym Tanajou lub Tanasoa z Driennika, w którym załoga „Św. Piotra i Pawła” faktycznie została dobrze przyjęta, było miasto portowe Quanzhou z prowincji Fujian, znane od XIII w. Europejczykom jako Zajton Marco Polo. Zostało ono zaznaczone także na mapie Beniowskiego. Płynąc z prądem, już 17 września z pomocą chińskich rybaków statek stanął na kotwicy w Tanasoa. Mamy w tym dniu informację o prowadzonym przez załogę handlu z Chińczykami i o tym, że obok statku natychmiast pojawiły się stateczki z dziewczynami, „które sprzedawały swoje wdzięki”. 19 września piloci wyprowadzili statek z portu i po 2 dniach „Św. Piotr i Paweł” szczęśliwie dotarł do Makau.

Jeden tylko fakt zasługuje tu na szczególną uwagę: przed przybyciem do Makau piloci zalecili zakotwiczyć statek na noc „wśród wysp zwanych Ladrones”. Jako pierwszy poprawnie zidentyfikował te wyspy kapitan Pasfield Oliver, który podobnie jak Forsterowie odwiedził Makau. Oliver umieścił w przypisach do swego wydania Pamiętników uwagę, że Ladrones Beniowskiego to była grupa małych wysepek w pobliżu Kantonu i Makau i że „nie należy ich mylić z Wyspami Mariańskimi” "77. Miałem okazję przekonać się, że faktycznie tak nazywali Portugalczycy skaliste wysepki wokół Makau. Nazwa ta sprawiała wiele trudności wcześniejszym (i nie tylko) interpretatorom żeglugi Beniowskiego, gdyż Magellan nazwę Ladrones (Wyspy Złodziejskie) nadał Wyspom Mariańskim z uwagi na kradzieże, jakich tam doznał. Beniowski także na

${ }^{75}$ W tłumaczeniu „Przylądek Bogactwa” - został tak nazwany ze względu na znajdujące się w pobliżu kopalnie złota.

${ }^{76}$ Wyspa Żółwich Jaj (Guiluandao) i Wyspa Żółwiej Góry (Guishandao).

77 P. Oliver, The Memoirs and Travels..., s. 441. 
swojej mapie określa Mariany obydwiema tymi nazwami: Marianneae ou Ladrones. Natomiast Portugalczycy z Makau znali pod nazwą Ladrones grupę wysepek rozrzuconych wokół enklawy. Żegluga od wysp Ladrones do portu Makau trwała zaledwie 5 godzin, więc wszelkie dywagacje o Marianach, którymi raczyli polskich czytelników Orłowski, Roszko czy Biernatt, były całkowicie bezpodstawne.

W zakończeniu chciałbym jeszcze skorzystać z możliwości uzupełnienia tego artykułu o następujące najnowsze informacje, uzyskane przeze mnie dzięki uprzejmości p. Jana Manikowskiego, Prezesa Fundacji im. M. Beniowskiego w Nowej Soli.

W dniu 11 maja 2018 r. odbyła się w Barze na Ukrainie Międzynarodowa Naukowo-Historyczna Konferencja „250 lat Konfederacji Barskiej”. Konferencja została sfinansowana przez Stowarzyszenie „Wspólnota Polska” ze środków otrzymanych z Kancelarii Senatu RP, a jednym z punktów programu było odsłonięcie w jej trakcie popiersia Maurycego Beniowskiego. Wśród wygłoszonych na niej 23 referatów aż 7 zostało poświęconych Beniowskiemu, jego żegludze przez Pacyfik i jego odnalezionej w 2011 r. w Warszawie rękopiśmiennej mapie, odrestaurowanej obecnie dzięki inicjatywie i środkom Fundacji. W jednym z wygłoszonych referatów pt. Maurycy Beniowski jako geograf $i$ kartograf jego autor - prof. Radosław Skrycki z Uniwersytetu Szczecińskiego wyraził następująca nietrafną opinię, która jestem zmuszony przy tej okazji sprostować. Zauważył on: „Zagadką pozostają dalsze losy mapy, aż do odkrycia jej w warszawskiej bibliotece. Najwyraźniej widać to w »zagubieniu« się Edwarda Kajdańskiego, który w kilku rozprawach pisał o zaginięciu mapy, gdy tymczasem mapa została odkryta, poświęcił jej fragment swojej kolejnej pracy, po czym, przygotowując pełną edycję Pamietników Beniowskiego, wrócił z niewiadomych powodów do tezy o zaginięciu karty, jednocześnie zamieszczając ja jako załącznik w owych Pamiętnikach".

Otóż ani się nie „zagubiłem”, ani nie przygotowywałem pełnej edycji Pamiętników z 2017 r. (choć figuruje na niej moje nazwisko jako tłumacza, autora przypisów, kilkunastu map w tekście i przedmowy), ani nie zamieszczałem ,z niewiadomych powodów" zaginionej i odnalezionej mapy Beniowskiego jako załącznika (bez jednego słowa komentarza) w Pamietnikach. Banalna prawda jest taka, że opracowałem Pamietniki do ich pierwszego wydania przez Oficynę Wydawniczą Volumen ponad 20 lat temu, lecz nie wiedziałem o zamiarze ich powtórnego wydania w grudniu 2017 r. Skutkowało to tym, że bez mojej wiedzy Volumen wydał Pamietniki bez konsultacji ze mna, nie uwzględniając dokonanych w międzyczasie odkryć i zmian, jakie nastąpiły w stanie wiedzy o żegludze Beniowskiego, zamieszczając we wspomnianym wydaniu zdezaktualizowane na przestrzeni tych lat mapy, przedmowę i komentarze. Drugie wydanie zostało opublikowane w niezrozumiałej dla mnie tajemnicy, bez mojej wiedzy i zgody, z naruszeniem obowiąującego prawa autorskiego, warunków zawartych wcześniej umów i przestrzeganych obecnie w całej Europie zwyczajów. O jego ukazaniu się w druku dowiedziałem się z Internetu, co pozbawiło mnie możliwości jakiegokolwiek wpływu na treść tej publikacji i w dotkliwym stopniu zburzyło moje najbliższe plany wydawnicze. 


\section{SUMMARY}

\section{BENYOVSZKY'S TRAVELS ALONG THE COAST OF EAST ASIA IN THE LIGHT OF THE LATEST FINDINGS (THE BONIN ISLANDS, JAPAN, LIUQIU ISLANDS, CHINA, MACAU)}

This article presents the latest findings from research on Maurice Benyovszky's travel through the Bering Sea and the North Pacific Ocean in 1771, with special focus on the implications for the findings carried by the 2011 discovery of Benyovszky's original map found at the Library of the Institute of Geography of Polish Academy of Sciences in Warsaw. This is the map that he handed over to duc d'Aiguillon, French Minister of Foreign Affairs, after his escape from exile and return to Europe. The time and circumstances of this discovery in the Warsaw collection of the Institute remain unknown. A widespread interest in Benyovszky's navigation through the Pacific Ocean was first aroused in academic circles in Europe at the turn of the 19th and 20th century, after the 1893 publication of English translation of his Memoirs and Travels, edited by Samuel Pasfield Oliver. The academic dispute that erupted lasted several years and involved many of the contemporary maritime historians and experts familiar with Benyovszky's life, among them: Prosper Cultru, James Wheeler Davidson, Benedykt Dybowski, János Jankó, Lajos Lewis Kropf, Ignacy Radliński, George Staunton, Lajos Thalloczy and others. Attempts of objective study of Benyovszky's contribution to maritime exploration resumed in the early 21 st century and involved an array of maritime historians from Europe, Asia and America, including the author of this article. The article attempts to summarise the findings from research on Benyovszky's biography and the implications of those findings for the attitude towards Benyovszky that has prevailed in the world over the last decades, viewing him as an - accidental, but still - explorer, who made it into maritime and exploration history. 